\title{
Diacronie
}

Studi di Storia Contemporanea

$N^{\circ} 7,3 \mid 2011$

«Spagna Anno Zero»: la guerra come soluzione

\section{Cine y guerra civil}

El conflicto que no termina

José-Vidal Pelaz López y Matteo Tomasoni

\section{(2) OpenEdition \\ Journals}

Edición electrónica

URL: http://journals.openedition.org/diacronie/3337

DOI: $10.4000 /$ diacronie.3337

ISSN: 2038-0925

Editor

Association culturelle Diacronie

Referencia electrónica

José-Vidal Pelaz López y Matteo Tomasoni, « Cine y guerra civil », Diacronie [En línea], № 7, 3 | 2011, documento 15, Puesto en línea el 29 julio 2011, consultado el 02 mayo 2019. URL : http://

journals.openedition.org/diacronie/3337 ; DOI : 10.4000/diacronie.3337 


\title{
Diacronie
}

\section{5/}

\section{Cine y Guerra civil}

\section{El conflicto que no termina}

\author{
José-Vidal PELAZ LÓPEZ * \\ Matteo TOMASONI **
}

La guerra civil ha sido y sigue siendo un tema de análisis, reflexión y debate tanto en España como en el extranjero. Desde el estallido mismo del conflicto hace 75 años el cine fue utilizado como agente propagandístico. Después, las películas han contribuido a crear un imaginario colectivo sobre aquel drama: hasta 1975 como elemento legitimador del estado franquista, después recuperando y ensalzando la causa republicana. Nuestro trabajo se basa en el estudio de una selección de películas de la primera década del siglo XXI (2001-2011) con el objetivo de analizar la visión que de la guerra ofrece el cine español en la actualidad. Consideramos el conflicto civil como un episodio histórico en continua (re)modelación y (re)interpretación, y por ello nos interesa abordar las estrategias mediante las cuales el cine acerca hoy en día esta cuestión a las nuevas generaciones de españoles, que no solo no vivieron ya aquella época, sino que además tienen un conocimiento superficial de los hechos históricos.

\section{Historia, memoria, guerra civil y cine}

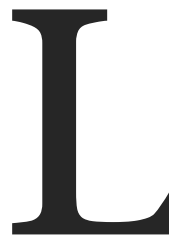

a Guerra Civil constituye sin lugar a dudas el hecho capital de la historia del siglo XX español. La fuerte carga ideológica de la contienda hizo que desde el principio la propaganda se convirtiera en un arma más al servicio de cada bando. Y, dado que ya en los años treinta el cine se había configurado como el medio de comunicación de masas por excelencia, no fue extraño que los contendientes lo utilizaran en su provecho. Terminada la guerra, los vencedores siguieron utilizando las salas oscuras para legitimar y reforzar su victoria. En este sentido fue paradigmática la producción de Raza (José Luis Sáez de Heredia, 1941), una película cuyo guión firmaba el mismo Franco y de claros ribetes autobiográficos. No obstante, ya durante la propia dictadura, de forma más o menos velada o 
metafórica, se producirían películas con fuerte carga antifranquista, caso de La caza (Carlos Saura, 1965). Un signo de los nuevos tiempos que se avecinaban fue, sin duda, que a comienzos de los años setenta, el director general de RTVE vetase el pase televisivo de Raza, por considerar poco oportuna su emisión ${ }^{1}$. Tras la muerte del dictador y la liquidación de la censura en 1977 la visión de la guerra civil en el cine español experimentaría una transformación decisiva ${ }^{2}$. Los cineastas más comprometidos no dudaron en plantear una revisión del significado y consecuencias de la contienda 3 .

A decir verdad el público español nunca manifestó gran preferencia por las películas sobre la guerra, ni durante el franquismo ni después. Quizá porque se trataba de una experiencia colectiva tan amarga que nadie tenía demasiado interés en verla reflejada en la pantalla, y quizá también porque todo el mundo se había formado ya su propia opinión sobre lo que ocurrió y no necesitaba que el cine viniera a explicárselo. Tras algunas polémicas intensas en los primeros años de la Transición, como sucedió con Las largas vacaciones del 36 (Jaime Camino, 1976), el ardor reivindicativo del cine español se fue calmando. Incluso llegaron cintas que abordaban la guerra desde una perspectiva desenfadada o humorística, como La vaquilla (Luis García Berlanga, 1985) o iBiba la banda! (sic) (Ricardo Palacios, 1987)4. De los 800 films realizados en España entre 1990 y 1999, tan solo media docena tuvieron como eje argumental el conflicto del 36. Para algunos se trataba de una prolongación tardía de un fantasmagórico «pacto del olvido» de la Transición. Para otros, una muestra de que el tema no interesaba a las jóvenes generaciones que pasaban por taquilla5.

${ }^{1}$ Se trataba de Adolfo Suárez. El episodio en FUENTES, Juan Francisco, Adolfo Suárez. Una biografía política, Madrid, Planeta, 2011, p. 89.

${ }^{2}$ Véase especialmente el recorrido hacia la democratización del cine que propone Magí Crusells: La guerra civil española: cine y propaganda, Barcelona, Ariel, 2000, pp. 217-223.

3 Sólo por citar algunos ejemplos: HERNANDÉZ RUIZ, Javier, PÉREZ RUBIO, Pablo, Voces en la niebla: el cine durante la Transición española (1973-1982), Barcelona, Paidos Iberica, 2004; CAPARRÓS LERA, José María, El cine español de la democracia. De la muerte de Franco al 'cambio' socialista (1975-1989), Barcelona, Anthropos, 1992; GÓMEZ BERMÚDEZ DE CASTRO, Ramiro, La producción cinematográfica española: de la transición a la democracia (1976-1986), Bilbao, Mensajero, 1989.

4 No obstante, «la obra de Berlanga consiguió irritar a quienes vieron en ella una falta de respeto a una guerra que todavía tiene abiertos sus odios y rencores» CRUSELLS, Magi, La guerra civil española: cine y propaganda, Barcelona, Ariel, 2000, p. 228.

5 Crusells sostiene de forma poco convincente que la demostración del olvido con respecto a la guerra queda patente en el hecho de que el regreso a España de los restos de Diego Martinez Barrio "pasó sin pena ni gloria», mientras que al entierro de la madre del Rey, María de las Mercedes, unos días antes, asistió en pleno el gobierno de José María Aznar. Ambos hechos ocurrieron a comienzos de 2000, pocos meses antes de la victoria por mayoría absoltua de Partido Popular. CRUSELLS, Magi, op. cit, pp. 18-19 
El comienzo del nuevo siglo ha venido acompañado por un intento de recuperación del pasado de la mano de la llamada «memoria histórica», un concepto que, al parecer, resulta de aplicación exclusiva a la Guerra Civil y al franquismo. Según los promotores de esta iniciativa, se trata tanto de honrar a las víctimas de la represión como de impedir que el olvido cubra con su manto a sus verdugos. El proceso ha culminado con la llamada Ley de Memoria Histórica, aprobada por el Congreso de los Diputados el 31 de octubre de 2007, que viene a regular el reconocimiento de todas las víctimas de la Guerra Civil y de la dictadura franquista, además, entre un sinnúmero de aspectos, de facilitar la apertura de fosas comunes con restos de asesinados por los sublevados en 1936.

La pretensión de edificar la Historia sobre la única base de la memoria es sencillamente una tarea imposible. La memoria, por definición es sesgada, incompleta, parcial, selectiva y subjetiva. La Historia no se construye solo a base de los recuerdos de sus actores, la Historia debe acreditar hechos, luego susceptibles de análisis e interpretación. Frente a la subjetividad de la memoria, la Historia no opone, como podría sugerirse, la objetividad inmaculada del investigador aséptico, sino la profesionalidad del estudioso que, junto al testimonio de los protagonistas, rastrea en busca de todo tipo de fuentes documentales. El objetivo final no es solo reconstruir una suma de dramas individuales, sino establecer e interpretar unos hechos que han afectado a una colectividad. La memoria puede permitirse ser selectiva, se tiende a olvidar aquello que nos perturba. La Historia no puede serlo, ya que debe esforzarse en mostrar todos los elementos que nos ayuden a comprender hasta donde sea posible una época y sus protagonistas 6 .

La tentación de utilizar la memoria colectiva para influir en el presente es tan antigua como la Historia misma. Con ello se pretende despertar emociones, conseguir legitimidades, estimular el sentimiento de pertenencia a un grupo, justificar la necesidad de determinadas actuaciones, promover el cierre de filas en torno a ideologías o proyectos. Por eso el cine es un instrumento tan valorado por los

\footnotetext{
${ }^{6}$ Pueden existir discrepancias serias en la memoria incluso entre los que combatieron en el mismo bando. En 1977 Jaime Camino rodó una película documental recogiendo testimonios sobre la Segunda República y la Guerra Civil. En La vieja memoria, título ciertamente premonitorio, aparecían destacadas personalidades de los dos bandos: Federica Montseny, Dolores Ibárruri, José María Gil Robles o Josep Tarradellas. Lo más llamativo resultó ser, no tanto el previsible enfrentamiento entre los puntos de vista de franquistas y republicanos, sino las contradicciones y choques entre anarquistas y comunistas a la hora de recordar algunos aspectos tales como las colectivizaciones de tierras o los sucesos de mayo de 1937 en Barcelona. No solo se trataba de que sus puntos de vista fueran distintos, sino que sus recuerdos lo eran también.
} 
promotores de la «memoria histórica», porque apela a lo emocional más que a lo racional, modifica la realidad según interese, ofrece un discurso ideológicamente cerrado y permite una identificación emocional entre el espectador y el drama que contempla (que no otra cosa es el cine). Goebbels decía que el cine debe «representar las auténticas vivencias de un pueblo, sus alegrías y sus penas, todo aquello que lo pueda conmover»7. En una entrevista concedida tras el estreno de Libertarias (1996), una película muy polémica por su cruda visión del bando nacional, su director Vicente Aranda explicaba que:

«En su día, en la primera elaboración del guión hicimos uso de un material informativo muy voluminoso, pero a partir de un determinado momento he preferido olvidarlo, no he querido saber que es lo que correspondía a una realidad documental y que es lo que era simplemente invención o, si se quiere, interpretación de los hechos»8.

Dicho de otro modo, la realidad de los hechos nunca debe interponerse a la hora de conseguir nuestros objetivos mediante el celuloide. Como afirmó ya hace tiempo Pierre Sorlin, «La película está íntimamente penetrada por las preocupaciones, las tendencias y las aspiraciones de la época» en que se produce, «es una de las expresiones ideológicas del momento»9. Por supuesto, la interpretación que se hace del pasado no es inmutable, depende de las circunstancias del presente en que se quiere actuar y no está en relación directa con el dictamen que los historiadores puedan haber establecido sobre la materia, sino con la coyuntura del momento. Goebbels también dijo algo al respecto de esto: «El cine es un arte de su tiempo. Aunque las películas transcurran en otros países u otras épocas, los argumentos deben adaptarse a la mentalidad de la sociedad en que se producen ${ }^{10}$.

Sería difícil de rebatir el hecho de que el cine español producido en la última década ofrece una visión de la guerra civil en línea con esta llamada «memoria histórica» que

\footnotetext{
7 ESPAÑA, Rafael de, El cine de Goebbels, Barcelona, Ariel, 2000, p. 17.

8 CRUSELLS, Magi, op. cit, p. 252. Por ejemplo, las protagonistas del film son violadas y asesinadas salvajemente por tropas moras, que por esas fechas (verano de 1936) no estaban combatiendo en el lugar donde acontecen los hechos (frente de Aragón).

9 SORLIN, Pierre, The Films in History. Restaging the Past, Oxford, Blackwell, 1980. Citado por: CAPARROS LERA, José $\mathrm{M}^{\mathrm{a}}$. Cien películas sobre Historia Contemporánea, Barcelona, Ariel, p. 17.

${ }^{10}$ ESPAÑA, Rafael de, op. cit., p. 18.
} 
se ha venido reivindicando desde la izquierda política ${ }^{11}$. Se trata, como veremos, de una filmografía que ofrece una visión del conflicto orientada a apoyar el discurso promovido por quienes, argumentado que durante la Transición democrática se produjo un pacto de silencio, consideran que ha llegado el momento de que la sociedad española conozca la verdad sobre los crímenes del bando vencedor de la guerra. Como apunta Julián Casanova:

«Frente a esa cultura del miedo y del olvido, una parte del cine español, pequeña pero muy significativa, explora hoy con sus imágenes la España de los perdedores. Es una reconstrucción que tiene mucho de recuperación ideológica, de memoria de militancia y de reivindicación de la herencia de los vencidos. Pero es también una lucha contra el falseamiento de los hechos del pasado» ${ }^{12}$.

La intencionalidad de este cine no es otra que transmitir a las nuevas generaciones de españoles que ya no vivieron el conflicto, que apenas han oído hablar de él y que lo han estudiado con la habitual desgana a lo largo de su proceso educativo, una visión mitificada de la contienda e idealizada de los perdedores, cuyo punto de vista se adopta sistemáticamente en las películas. Para ello «necesitamos del cine, de su eficacia narrativa y del poder de sus imágenes. Un cine que no sea solo instrumento de denuncia, sino que aporte también una voluntad de conocimiento, que convierta el pasado en lección de tolerancia para los jóvenes»13. Esto último parece, sin duda, lo más difícil de conseguir, dado el planteamiento de la mayoría de las cintas. En el fondo se trata de impedir que la Guerra civil española pase a ser definitivamente solo historia. Debe ser también memoria, es decir, tiene que permanecer viva en el recuerdo colectivo para seguir de alguna manera, influyendo en el presente y el futuro. Y ahí radica la importancia del cine.

Hemos seleccionado para nuestro estudio 18 largometrajes de ficción producidos o coproducidos en España entre 2001 y 2011, que abordan de una u otra forma la guerra civil y sus consecuencias. Se trata de Silencio roto (Montxo Armendáriz, 2001), La luz prodigiosa (Miguel Hermoso, 2002), Una pasión singular (Antonio Gonzalo, 2002)

\footnotetext{
${ }^{11}$ «La memoria de la guerra civil y del franquismo se convierte al inicio de la década en uno de los ejes fundamentales de la opisición a un gobierno de derechas que sigue reivindicando los servicios prestados a España por Franco y favorece los intereses y aspiraciones de la Iglesia» IBÁÑEZ, Juan Carlos, «La Guerra Civil en el cine español de la primera década del siglo XXI» en IBÁÑEZ, Juan Carlos, ANANIA, Francesca (coords.), Memoria histórica e identidad en cine y televisión, Sevilla y Zamora, Comunicación Social ediciones y publicaciones, 2010, p. 103 ${ }^{12}$ CASANOVA, Julián, «Guerra y dictadura en el cine español», en El País, 8-9-2008.

13 Ibidem.
} 
Soldados de Salamina (David Trueba, 2003), El lápiz del carpintero (Antón Reixa, 2003), Triple agente (Eric Rohmer, 2004), Juegos de mujer (John Duigan, 2004), El laberinto del fauno (Guillermo del Toro, 2006), Las trece rosas (Emilio Martínez Lázaro, 2007), La mujer del anarquista (Peter Sehr y Marie Noëlle, 2008), La buena nueva (Helena Taberna, 2008), Los girasoles ciegos (José Luis Cuerda, 2008), Pájaros de papel (Emilio Aragón, 2010), Balada triste de trompeta (Alex de la Iglesia, 2010), Pan negro (Agustí Villaronga, 2010), Caracremada (Lluis Galter, 2010), Ispansi (Carlos Iglesias, 2010) y Encontrarás dragones (Roland Joffé, 2011). No son muchos teniendo en cuenta el volumen de producción de la industria cinematográfica nacional, una de las más activas del mundo. En esa década se facturaron nada menos que 1.510 películas. Tan solo en el año 2011 se contabilizaron 201 estrenos $^{14}$. Estos datos nos permiten ya una primera aproximación a la cuestión. Se trata de un tema que interesa poco a las productoras, si bien se observa un cierto repunte en los últimos años, que podríamos hacer coincidir con la polémica sobre la Ley de la Memoria histórica de 2007. Cuatro títulos en 2008 y cinco en 2010, suman la mitad del total concentradas en tan solo dos años.

La impresión de que se trata de un cine poco atractivo se ve corroborada con el análisis de los datos de espectadores. Tan solo un título se coloca por encima del millón de localidades vendidas y únicamente otros dos superan el medio millón. Siete cintas no pasan la barrera de los cien mil espectadores. Y alguna como Caracremada ni siquiera la de los tres mil. La cinta más taquillera de este lote fue El laberinto del fauno, una película atípica por cuanto aborda la cuestión desde el género fantástico, mucho más popular entre los consumidores juveniles del séptimo arte. Las otras dos más destacadas fueron Las Trece Rosas y Los girasoles ciegos, títulos sobre los cuales se concentró una indudable atención mediática. Es interesante constatar que en esos mismos años otras películas españolas superaron ampliamente el millón de espectadores y que alguna, como La gran aventura de Mortadelo y Filemón (Javier Fesser, 2003) y El orfanato (Juan Antonio Bayona, 2007) fueron las más vistas de sus años respectivos, por encima de superproducciones del calibre de Piratas del Caribe II y III (Gore Verbinski, 2003 y 2007). También conviene poner de relieve, para establecer términos comparativos adecuados, que la película española más vista de esta década fue Los Otros (Alejandro Amenábar, 2001) con casi 6,5 millones de

\footnotetext{
${ }^{14}$ Se incluye en esos datos tanto largometrajes de ficción como de no ficción. Fuente:

URL: < http://www.mcu.es/cine/MC/CDC/Evolucion/GraficosEvolucion.html > [visitado el 26/o6/2011].
} 
espectadores, solamente superada por El señor de los anillos: la Comunidad del Anillo (Peter Jackson, 2001) que sobrepasó los siete millones.

La cuestión no es pues cuantitativa. Ni por número de películas realizadas ni por espectadores en sala la guerra civil resulta ser un asunto atractivo, ni por supuesto rentable. El interés de esta filmografía es, pues, eminentemente cualitativo. Lo que interesa es analizar aquí es si existe una visión fílmica «oficial», canónica podríamos decir, de la guerra del 36. Establecida esa cuestión no será difícil convenir que el hecho de que las películas sean pocas o los espectadores escasos, se convierten en cuestiones menores al lado del hecho de que no exista una visión alternativa, "políticamente incorrecta». 


\section{Así en la paz como en la guerra}

Lo primero que destaca en esta serie de películas es que en realidad no muestran la guerra ni se centran en los tres años de conflicto. La filmografía española sobre la contienda está huérfana de grandes producciones centradas en las principales batallas o en los acontecimientos del periodo. Esta aparente paradoja se resuelve utilizando la guerra como desencadenante dramático para explicar todo lo que vendrá después. Las películas hablan de las consecuencias de la guerra mas que de la guerra misma para de esta manera establecer ante el espectador una nada sutil relación entre el antes y el después de 1939. Así el franquismo vendría a ser la continuación de la guerra por otros medios y el conflicto no habría terminado, al menos, hasta 1975.

La guerra no ocupa la totalidad del metraje de ninguna de las películas analizadas. Aparece como un episodio más dentro de una trama dramática en Juegos de mujer, en Pájaros de papel y en Encontrarás dragones, o sirve de preámbulo a una acción que se desarrollará posteriormente, como en Balada Triste de Trompeta. La acción de la mayor parte de los films arranca, o bien de los primeros instantes del conflicto, o bien de los últimos. Es decir, de los dos momentos en los que los sublevados pusieron en marcha las medidas represoras más duras: el 18 de julio con el alzamiento nacional $-\mathrm{y}$ las detenciones y ejecuciones del verano del 36- y el final de la guerra, con la entrada de los nacionales en Madrid y el desencadenamiento de la represión subsiguiente. Entre las que optan por lo primero podríamos destacar Una pasión singular, film en el que se narra por medio de flashbacks la vida de un Blas Infante detenido y esperando la muerte. Esta cinta es la que más se detiene en los antecedentes y el desencadenamiento del conflicto, poniendo de relieve la trascendencia histórica de la II República. En El lápiz del carpintero, apenas se esboza la etapa republicana, quedando claro en cualquier caso que fue una etapa de libertad truncada violentamente por la acción de los facciosos. La luz prodigiosa, por su parte, tiene su arranque en uno de los numerosos asesinatos del verano del 36 , proponiendo luego al espectador un juego basado en la idea de que García Lorca fuera uno de los fusilados, que milagrosamente hubiera conseguido sobrevivir ${ }^{15}$. La buena nueva reconstruye el 18 de julio en un

15 El tema de los «fusilamientos fallidos» aparecía ya como un elemento central en Raza y aparecerá otra vez en Soldados de Salamina e incluso (aunque de otra manera) en El lápiz del carpintero. En Una pasión singular se muestra también la posibilidad de que Blas Infante hubiera podido sobrevivir a su ejecución, si hubiera recibido ayuda en un convento hacia el que se arrastró, tras ser tiroteado. 
pequeño pueblo de Navarra. Entre los largometrajes que prefieren la segunda opción, es decir, situarse en los últimos compases de la guerra, podríamos situar a Soldados de Salamina, que muestra la caída de Cataluña y la desbandada del ejército republicano. Y también Las trece rosas, que se ubica en el Madrid en los días que rodearon al desfile de la Victoria.

Todas las películas sin excepción son narradas desde el punto de vista de los perdedores de la guerra, que son los que evidentemente se llevaron la peor parte después de 1939. La opción de obviar los acontecimientos posteriores a 1936, incluso los del verano de ese año en la otra zona, exime a los realizadores de la necesidad de mostrar los abusos y asesinatos que igualmente se cometieron en la llamada España leal, donde como es bien sabido, se desencadenó un descontrolado proceso revolucionario. Tan solo en Soldados de Salamina se muestra a los republicanos ejecutando a los franquistas, pero hay que recordar que se trata de combatientes y no de civiles, y que la razón de ser última de la película es mostrar la humanidad del «miliciano anónimo» que perdona la vida de Sánchez Mazas.

Las diversas formas de resistencia ante los vencedores o simplemente de supervivencia ante el nuevo estado de cosas centran el metraje de muchas de estas películas. El maquis es el protagonista de Silencio roto, Caracremada o el Laberinto del fauno. La represión es el eje argumental de Las trece rosas. La figura del «topo» aparece sobre todo en Los girasoles ciegos, pero también en Pan negro y en La buena nueva. Particular interés reviste la actuación de los combatientes que enlazaron la Guerra española con la Segunda Guerra Mundial. La idea es mostrar que la lucha contra el fascismo comenzó en España en 1936 y continuó en los campos de batalla europeos a partir de 1939. Esta cuestión es un aspecto fundamental de la trama de Juegos de mujer y de Triple agente, dos películas curiosamente de directores no españoles. La epopeya de los republicanos que lucharon contra los nazis después de 1939 centra la historia de Soldados de Salamina y La mujer del anarquista. Por su parte, en El laberinto del fauno, la acción comienza en 1944, y los maquis reciben con alborozo la noticia del desembarco aliado en Normandía, paso previo a la liberación de Francia ... y también de España. En Ispansi se opta por otra de las dimensiones del mismo drama: la historia de los niños de la guerra y de los adultos que marcharon con ellos a la Unión Soviética y se vieron sorprendidos allí por la invasión nazi.

Muchas de estas cintas recuerdan a las películas sobre la Resistencia en la guerra mundial. La diferencia con ellas estriba en que el enemigo a batir no es un invasor extranjero (los nazis), sino una versión local del fascismo, que oprime a su propio pueblo. En Los girasoles ciegos o en Juegos de mujer la vinculación entre la España de 
Franco y la Alemania nazi aparece explícitamente, mientras que en otras como $E l$ laberinto del fauno es más indirecta, pero no menos evidente ${ }^{16}$.

La dureza de la situación explica la constante alusión al exilio como única vía de escape, toda vez que la lucha armada fracasa o se encuentra en vía muerta. México parece ser la salida a los protagonistas de El lápiz del carpintero, también se alude a ella en las Trece rosas. En Los girasoles ciegos es Portugal la vía de escape hacia América, en Ispansi, es la Rusia soviética, mientras que en Pájaros de papel, el destino es la Argentina y en Pan negro, o La mujer del anarquista la esperanza está representada en el exilio francés. Tan solo en uno de los largometrajes la resistencia obtiene sus frutos. En El laberinto del fauno, el maquis causa a los fascistas una derrota decisiva. El carácter fantástico del relato permite al director esta libertad creativa, de imprevisibles consecuencias ante un público juvenil poco avisado.

El franquismo por lo tanto es descrito como un régimen en guerra permanente contra su propio pueblo. Una descripción, que, si bien, se circunscribe de facto a los años de la inmediata posguerra, tiene el efecto de transmitir al espectador de hoy una imagen global del régimen que se extendería al menos hasta su desaparición formal en 1975. El retrato sórdido y deprimente de España en Balada triste de trompeta, estableciendo una suerte de paralelismo entre un viejo y desvencijado circo y la decadente dictadura a comienzos de los setenta, es bien expresivo al respecto. Como apunta Sánchez Biosca: "de acuerdo con una convención no escrita, pero aceptada casi unánimemente, cuando se trata de zambullirse en ese larguísimo periodo que fue el franquismo se impon(e) una sinécdoque: la sordidez y desolación de los años 40 y, a lo sumo, 50"17.

Si la conexión entre la guerra y el franquismo se establece casi por si sola, más sugerente resulta el intento de establecer un vínculo emocional entre los perdedores de la guerra y la España actual. En algunos largometrajes se recurre a la técnica del flashback: la acción arranca en nuestros días y los protagonistas ponen en marcha una investigación que les lleva hacia atrás en el tiempo. En La luz prodigiosa Miguel Hermoso se pregunta que ocurriría si se hubiese descubierto en la España de los años ochenta que García Lorca seguía vivo. En Soldados de Salamina David Trueba rinde sentido homenaje a los ignorados combatientes antifascistas de los campos de batalla español y europeo a través de la figura de un viejo exiliado en un geriátrico francés. En

${ }^{16}$ De hecho en la idea inicial para la película la acción se desarrollaba en un pais ocupado de Europa durante la II Guerra Mundial, y fue la insistencia de Guillermo del Toro la que hizo que el escenario se trasladara definitivamente a la España de los cuarenta.

17 SÁNCHEZ-BIOSCA, Vicente, Cine de historia, cine de memoria: la representación y sus límites, Madrid, Cátedra, 2006, p. 67. 
Encontrarás dragones un periodista indaga sobre su padre, amigo personal de Escribá de Balaguer, lo que permite a Roland Joffé moverse en el tiempo, desde comienzos del siglo XX, a los años treinta y luego los ochenta. En El lápiz del carpintero, el viejo guardia civil rememora los años de la guerra en la barra de un club de alterne, donde ahora se encarga de la limpieza. Otras veces se prefiere alargar la trama hasta un epílogo final situado tras la muerte del dictador, caso de Pájaros de papel, en que el actor que vuelve de América tiene un emocionado recuerdo hacia aquellos duros tiempos de la posguerra, o en Ispansi, donde tras vivir cuarenta años de duro exilio en la URSS, el protagonista constata que ya a nadie parece importarle el fallecimiento de Franco. Por su parte, en Las trece rosas, Emilio Martínez Lázaro opta por enviar un mensaje muy directo al espectador de la sala oscura, mediante la lectura en off de la carta que una de las condenadas a muerte escribe a su hijo, que incluye la frase: «Que mi nombre no se borre de la historia». De alguna forma se espera que el público de hoy deduzca que aquel sacrificio no fue en vano, pues nuestra sociedad, tras largos años de ignominia, ha acabado erigiéndose sobre los valores que aquellas valientes mujeres y muchos como ellas, defendieron con su sangre ${ }^{18}$.

\section{Vencedores y vencidos}

Si del análisis de las estrategias argumentales de las películas seleccionadas, pasamos al estudio de los personajes, la impresión dominante vuelve a ser similar. La adopción del punto de vista de los perdedores en la construcción del relato cinematográfico se complementa con el retrato maniqueo de los personajes, que aparecen divididos en dos grupos muy claramente diferenciados según pertenezcan a uno u otro bando. Apenas hay matices en ellos, no puede haberlos cuando se opta por una dialéctica de víctimas y verdugos.

Entre los llamados nacionales destacan de manera habitual los falangistas (y carlistas), los militares (y guardias civiles) y los sacerdotes. Son los representantes de la España de Franco, que se comportan de manera despiadada y brutal. En el verano del 36 porque aterrorizar al adversario es la única manera de asegurar la victoria, y

\footnotetext{
18 «Madre, madrecita, me voy a reunir con mi hermana y papá al otro mundo, pero ten presente que muero por persona honrada. Adiós, madre querida, adiós para siempre. Tu hija que ya jamás te podrá besar ni abrazar (...) Que no me lloréis. Que mi nombre no se borre de la historia». Existe un documental que narra también esta historia titulado precisamente Que mi nombre no se borre de la historia (Verónica Vigil y José María Almela, 2004).
} 
después, porque cualquier resto de resistencia debe ser aniquilado de cara a la construcción de la nueva España.

Los falangistas presentan un perfil casi psicopático. En El lápiz del carpintero, Zalo, no solo disfruta con los paseos y asesinatos nocturnos, es violento con su propia familia, maltratando también a su sufrida esposa, lo que en último término le acarreará el castigo por mano de su cuñado. El capitán de Falange de La buena nueva se manifiesta duro e inclemente contra los rojos, pero tampoco ve con buenos ojos a los carlistas y desconfía hasta del sacerdote. En el arranque de Las trece rosas, un falangista obliga a un anciano a cantar el Cara al sol y después le golpea al no saberse la canción, es el aviso de la represión que se cierne sobre Madrid tras la victoria. Un lugar destacado en este muestrario lo ocupa, sin lugar a dudas, el único falangista real que aparece en estas películas: Rafael Sánchez Mazas en Soldados de Salamina. Desprovisto de su poder y su fuerza, reducido a la condición de prisionero, este fundador de Falange y amigo de José Antonio aparece desvalido e indefenso. A pesar de la responsabilidad que recae sobre sus hombros en el estallido de la guerra civil, salva la vida gracias a la generosidad de un miliciano que le deja escapar, prueba evidente de la superioridad moral del bando republicano. La única excepción relativa a este perfil la tenemos en Jorge, falangista de primera hora, duro y fanático, hermano de la protagonista de Ispansi. Tras la guerra española, se incorpora a la División Azul y al encontrarse con españoles del «otro bando» en el frente de Leningrado, les salva la vida ante un pelotón de ejecución alemán, una nota de solidaridad entre hermanos que combaten ahora tan lejos de casa. Excepcional es la aparición de algún carlista entre los títulos seleccionados, es el caso de Hugo en La buena nueva, un cobarde, delator y chantajista que se autolesiona para no ir al frente (como su hermano, que vuelve en un estado lamentable) y que aprovecha las circunstancias para forzar al matrimonio a la esposa de un republicano asesinado por él mismo. No consta expresamente la militancia del alcalde interpretado por Sergi López en Pan negro, pero podemos incluirle también en este grupo por cuanto representa a la ideología del llamado Movimiento nacional. Se trata de un tipo brutal, que aprovecha su posición dominante para hacer ajuste de cuentas con los «rojos» del pueblo.

Algo más equilibrado resulta ser el retrato que se ofrece de los militares y guardias civiles. Los dos más duros resultan ser los que se enfrentan con los maquis, después de 1939. En concreto el sargento de Silencio roto y, sobre todo, el capitán Vidal, interpretado de nuevo por un brutal Sergi López en El laberinto del fauno. Este personaje compendia la quintaesencia del militar franquista en el imaginario izquierdista. Violento, torturador, sádico, machista, asesino, no tiene ninguna 
contemplación con sus enemigos ni con aquellos, que incluso en su propia familia, osan llevarle la contraria. Resultaría casi ridículo en su depravación si no fuera porque se mueve en el contexto de una película de corte fantástico, en la que desempeña el papel del monstruo presente en un relato infantil. La paradoja que busca forzar Guillermo del Toro en la mente del espectador, es que el mundo real (la posguerra) resulta ser bastante más aterrador que el mundo imaginario de duendes y faunos, donde la protagonista busca refugio. La muerte del capitán a manos del maquis triunfante, restablece a la vez el equilibrio entre el bien y el mal y entre el mundo real y el ficticio. La película de del Toro realiza una impagable aportación a la creación de ese franquismo mítico, tan del gusto del cine de los últimos años ${ }^{19}$.

Un personaje bastante más complejo resulta ser el guardia civil Herbal interpretado por Luis Tosar en El lápiz del carpintero. Se trata de un tipo rudo, primario, presionado por su cuñado falangista, que vive entre el odio por los «rojos» (y la lealtad a los sublevados) y la admiración callada hacia el médico republicano protagonista. Dentro de este universo militar cabe destacar al capitán Montero, interpretado por Fernando Cayo, en Pájaros de papel. En la película parece como contrapunto de sus subordinados, dispuestos siempre a abusar de la situación de privilegio que les concede su uniforme. Representa a aquella parte del Ejército que probablemente vio como necesario el Alzamiento del 18 de julio, pero que después de la guerra no era tan partidario de mantener en el poder de forma indefinida al general Franco. Tan es así que organiza sin éxito el intento de asesinato del Caudillo. Por cierto, que la posibibilidad del magnicidio aparece también en La mujer del anarquista, en esta ocasión a manos de un comando anarquista y en Las trece rosas, como excusa que da pie a la detención de las protagonistas. También el general aparece en Balada triste de trompeta, en esta ocasión en una cacería, paradigma de la brutalidad del régimen por él encarnado. La figura del Caudillo es mostrada a través de imágenes del NODO en otras cintas como Soldados de Salamina o Pájaros de papel. Su imagen para los republicanos derrotados representa la brutalidad del poder y el rostro de una dictadura implacable.

La Iglesia católica es junto a las fuerzas armadas y la Falange, el tercer elemento que configura las fuerzas dominantes en la nueva España. Su calificación de la guerra como «cruzada» y su apoyo a la dictadura la consagraron como uno de los pilares del régimen. Tres de las películas seleccionadas centran su argumento en los sacerdotes, si

19 Sorprendentemente para algunos autores Del Toro demuestra en su película «hasta donde puede llegar el cine de género contemporáneo (...) en la imprescindible tarea de atraer para la causa de la Historia a nuevos públicos cinematográficos», IBÁÑEZ, op. cit, p. 85. 
bien en otras varias aparecen de forma incidental y casi siempre presentados de una misma manera: como cómplices y beneficiarios de la dictadura ${ }^{20}$. Los girasoles ciegos muestra a un diácono que tras combatir en la guerra, ve flaquear su fe, fundamentalmente por su imposibilidad de mantener el voto de castidad. La película en algunos pasajes parece evocar al clásico del cine franquista Balarrasa (José Antonio Nieves Conde, 1951), pero con un mensaje completamente antitético. Mientras que Balarrasa encuentra la fe en la guerra y después de ella se entrega al sacerdocio, el protagonista de Los girasoles ciegos (de nombre Salvador) sigue el camino contrario. Hay incluso una escena en ambas cintas extrañamente coincidente: cuando los dos protagonistas se despojan de su uniforme militar que guardan en un armario y se visten con las ropas talares, bajo la atenta mirada de un crucifijo ${ }^{21}$. La película no ahorra detalles para mostrar la hipocresía y la doble moral de esta Iglesia de los vencedores, omnipotente y soberbia, a cuyo cuidado, por si fuera poco los perdedores deben confiar la educación de sus hijos ${ }^{22}$. Las secuencias (dos) en las que se ve a los curas haciendo cantar a los niños el Cara al sol, son suficientemente expresivas.

La buena nueva aborda la cuestión de una forma aparentemente más neutra. Miguel, el joven párroco de un pueblo navarro, se encuentra dividido entre apoyar a los defensores de la fe católica que se suman al Alzamiento y amparar a los perseguidos por estos siguiendo el mensaje evangélico. Mientras que la Iglesia oficial, encarnada por el Obispo, busca contemporizar, el párroco se acabará implicando en ayuda de los más débiles hasta comprender que su sacerdocio es incompatible con el mensaje de Cristo. La superiorioridad moral de los perdedores, queda de nuevo puesta de manifiesto. Cualquier persona, incluso un sacerdote, que primara la justicia sobre otras consideraciones, debería comprenderlo así y actuar en consecuencia.

Un caso aparte lo constituye Encontrarás dragones, una película atípica producida parcialmente con capital español y dirigida por Roland Joffé. La cinta se desmarca de la visión dominante en la cinemtografía española sobre la Iglesia y la guerra, ofreciendo una visión, para algunos hagiográfica, del fundador del Opus dei. En todo caso el sentido de la obra vendría a ser la denuncia de la brutalidad de la guerra y la

\footnotetext{
${ }^{20}$ En Pan negro, por ejemplo, el cura se niega a oficiar el entierro del padre del niño protagonista, militante de izquierdas. Hay también alguna excepción: en Pájaros de papel, un anciano sacerdote facilita la huida a los cómicos en fuga.

${ }^{21}$ El protagonista de Los girasoles ciegos vuelve a ponerse el uniforme cuando decide ir a abusar sexualmente de la esposa del «topo».

${ }^{22}$ En Pan negro la alternativa que se plantea es entre un maestro borracho y pederasta y los escolapios.
} 
exploración de como una situación límite de esas características afecta a la espiritualidad de las personas que la viven.

Al lado del bestiario franquista instalado en el imaginario del cine español, conviven los representantes del bando republicano. En líneas generales son presentados como personajes positivos, idealistas, un tanto inconformistas, y defensores de la libertad y la democracia encarnadas en la legalidad republicana. Se trata de un perfil genérico, en el que se diluyen las particularidades, y hasta hostilidades que separaban a los llamados «antifascistas» antes y después de 1936 y que estuvo en buena medida en la raíz de su derrota. Al considerar la guerra como un enfrentamiento entre libertad contra tiranía, de fascismo contra democracia, no tiene demasiado sentido en detenerse a explicar las diferencias que pudieran existir entre un socialista de Indalecio Prieto con otro de Largo Caballero, o entre un anarquista, un republicano de Azaña y un nacionalista catalán o vasco. La adscripción ideológica de los protagonistas no es importante en esta lucha contra el enemigo común. Ciertamente Ramón Vila, el protagonista de Caracremada es anarquista de la CNT, como lo es Justo Calderón, en La mujer del anarquista, y la mayor parte de las conocidas como Trece rosas, pertenecieron a las Juventudes socialistas. Pero la cuestión ideológica no es importante a efectos dramáticos. De lo que se trata es de mostrar las penalidades que estos luchadores por la libertad padecieron por enfrentarse a los franquistas. No se entra a considerar si algunas de las ideologías amparadas bajo el paraguas republicano -como el comunismo a la soviética - pudieran ser tan totalitarias como el propio fascismo.

La autocrítica no es un rasgo presente en esas cintas que no se detienen a valorar o presentar los errores propios, sino tan solo la brutalidad del enemigo. Tampoco se considera necesario explicar las causas profundas de la guerra, más allá del golpe de Estado del 18 de julio y de genéricas alusiones a las diferencias sociales entre pobres y ricos, ni aparecen, con alguna salvedad más arriba señalada, los posibles atropellos cometidos en el bando republicano.

En la galería de personajes que pueblan la causa del Frente Popular encontramos una ponderada mezcla entre burgueses de izquierdas y gente de clase humilde. Esa combinación de víctimas del fascismo está perfectamente encarnada en los presos que pueblan las cárceles improvisadas montadas tras el alzamiento militar tal y como se puede ver en Una pasión singular y El lápiz del carpintero. Destacan intelectuales como Blas Infante (Una pasión singular), el propio Lorca (La luz prodigiosa), médicos (El lápiz del carpintero, La buena nueva, El laberinto del fauno), profesores (Los girasoles ciegos, Ispansi), locutor de radio (La mujer del anarquista), artistas (Pájaros de papel, La buena nueva, Balada triste de trompeta). Por el otro lado encontramos 
gente del pueblo sencilla como las jóvenes de Las trece rosas, o campesinos ( $E l$ laberinto del fauno, La buena nueva, Pan negro). Este caleidoscopio humano vendría a subrayar la causa de la República como «la causa del pueblo» y la idea de que el franquismo careció de apoyo social y solo se impuso por la fuerza.

Podríamos señalar algunos personajes «fronterizos» entre un bando y otro, si bien en todos los casos, acaban cruzando la línea imaginaria que los separa inclinándose por el republicano. En Ispansi y Las Trece rosas aparecen sendas mujeres católicas que son víctimas de su propio bando. En La buena nueva, el sacerdote interpretado por Unax Ugalde, abandona los hábitos ante la falta de humanidad de los nacionales.

Resulta oportuno señalar aquí la preferencia de los guionistas por mostrar personajes femeninos e infantiles. Se trataría de resaltar por un lado su mayor indefensión en un mundo violento dominado por hombres y, por otro, sobre todo en el caso de los niños, remitirse a ellos como aquellos en quienes se encarna la esperanza de justicia en el futuro. Es la idea que transmite el final de las Trece rosas, que sin embargo, contrasta brutalmente con el desenlace de Pan negro, en el que la victoria de los franquistas pasa incluso por arrebatar los hijos a los perdedores. La elección de «historias con niños» podría deberse al intento de captar el interés de «nuevas generaciones de espectadores en su mayor parte alejadas cultural e intelectualmente de los acontecimientos que dieron origen o siguieron al conflicto bélico»23. Sería el caso de Los girasoles ciegos o Pájaros de papel donde el mismo actor (Roger Príncep) personifica a la perfección dos niños (muy distintos entre ellos, pero víctimas del mismo sistema) que experimentan las dificultades de la vida en la posguerra. En ambos casos los inocentes ojos del joven protagonista conectan al espectador con un pasado dramático, que en buena medida le es ajeno ${ }^{24}$.

\section{El cine español en su laberinto}

El director Agustín Díaz Yanes, en la presentación de su película Alatriste (2006) declaró: «Es tan difícil hacer buenas películas históricas en España por una cuestión de presupuesto, pero sobre todo porque tenemos un problema nacional: los españoles estamos muy peleados con nuestra historia» ${ }^{25}$. Y si del siglo XVII pasamos al XX cabría preguntarse incluso hasta que punto un sector de la sociedad española está dispuesto a

23 IBÁÑEZ, Juan Carlos, op. cit., p. 95.

24 También hace doblete Ivana Baquero en largometrajes como El laberinto del Fauno y La mujer del anarquista.

${ }_{25}^{2}$ PAYÁN, Miguel Juan, La historia de España a través del cine, Madrid, Cacitel, 2007, p. 4. 
considerar que la Guerra Civil y el franquismo son ya definitivamente Historia, o deben seguir estando presentes en la vida nacional a través de polémicas iniciativas como la de la Memoria Histórica ${ }^{26}$.

Esta sería por tanto la cuestión esencial que deberíamos formularnos para entender el sentido y el alcance del cine español sobre la Guerra civil. Evidentemente por el celuloide analizado transitan muchos personajes reales, históricos, como Blas Infante, García Lorca, las trece rosas, Caracremada, Escribá de Balaguer o el propio Francisco Franco. Otros proceden de adaptaciones literarias, como Los girasoles ciegos, Soldados de Salamina, Pan negro, o El lápiz del carpintero. Su origen es indiferente. Personajes reales y de ficción se mezclan en una combinación que no busca ni mejorar el conocimiento del pasado ni promover un debate sobre él, sino que su finalidad última es la de estimular nuestra emotividad tornando en secundario la comprensión y el análisis racional de los hechos históricos narrados ${ }^{27}$. En opinión de Sánchez-Biosca, lo relevante no es tanto el discurso ideológico defendido por películas como las que hemos analizado, sino su contribución a lo que él llama «la formación de un estándar memorístico del franquismo» que ha llegado a sustituir en la sociedad el tradicional papel de la escritura histórica. El cine desempeñaría asi un relevante papel como maquinaria de pseudohistorización ${ }^{28}$. Por supuesto, esta no es una característica exclusiva del caso español ya que el cine se basa ante todo en la transmisión de emociones más que en la de conocimientos. Y cuando se trata de una película histórica la necesidad del vínculo emocional se convierte en una necesidad para atrapar a un espectador que o bien desconoce los acontecimientos que se narran o tiene de ellos una impresión superficial. Lo que llama la atención en el caso de la cinematografía española sobre la guerra es que el discurso sea tan monolítico e ideológicamente cerrado y que el objetivo sea mantener vivo determinado pasado para influir en el presente tantos años después de concluido el conflicto ${ }^{29}$.

${ }^{26}$ En La buena nueva el cura protagonista se dedica a trazar mapas que señalen las tumbas donde reposan los asesinados en el verano trágico del 36. En la película se dice «Podemos evitar que les maten otra vez con el olvido».

${ }^{27}$ En el arranque de La buena nueva podemos leer una cartela que dice: «Una historia inspirada en hechos reales".

${ }^{28}$ SÁNCHEZ-BIOSCA, Vicente, op. cit., pp. 80-81.

29 Veamos por ejemplo el caso de Las Trece rosas. Ya en el año 1985 el suceso relacionado con las trece rosas fue investigado por el periodista Jacobo García, en un artículo para la revista Historia 16. Unos años mas tarde, el escritor Jesús Ferrero vuelve a retomar los hechos para exponerlos de forma novelada en su libro Las Trece rosas (Siruela, Madrid, 2003). En 2004, la historia es llevada al cine, en un documental dirigido por Verónica Vigil y José María Almela titulado Que mi nombre no se borre de la historia, y en este mismo año aparece el libro Trece Rosas Rojas: la historia más conmovedora de la Guerra Civil, (Madrid, Temas de hoy, 2005) 
Después de la muerte de Franco el cine español se ha empeñado en mostrar la guerra casi exclusivamente desde el bando perdedor, cayendo en muchos casos en lo mismo que criticaba de las películas franquistas: la manipulación y el uso propagandístico del pasado. Un observador desprevenido podría tener la impresión de que las películas hechas desde 1975 son las que se hubieran hecho desde 1939 si la República hubiera ganado la guerra. Que las películas del franquismo fueran propagandísticas, que lo eran, no quiere decir ni mucho menos que las películas que ofrecen la versión opuesta no sean también propaganda ${ }^{30}$. Porque una cosa es la exaltación romántica de los derrotados y otra la reivindicación permanente de su causa. El cine norteamericano, por ejemplo, se ha mostrado notablemente condescendiente con la causa del Sur en la guerra de Secesión, pero por muy caballeros que fueran los sudistas, no se puede olvidar que luchaban en defensa de la esclavitud. La derrota no lava todos los pecados de los derrotados.

Resulta comprensible que durante el propio conflicto se hiciera en ambos bandos cine de batalla, también que después de 1939 se produjeran películas de exaltación de la victoria y luego, después de 1975, de glorificación romántica de la derrota. Lo sorprendente en el caso español es que 70 años después de terminada la guerra se siga haciendo un cine de combate ideológico. Desde 1939 a 1975 transcurrieron 36 años de franquismo y desde 1975 a 2011 han pasado ya otros tantos. Cabría pensar de manera razonable que ya existe una perspectiva que nos permite ver el pasado con un cierto distanciamiento crítico. Pero es evidente que esta no es una opinión ni mucho menos unánime, ni siquiera entre los profesionales de la historia: «Treinta años de democracia (...) no han sido suficientes para borrar la cultura del miedo que el franquismo implantó», por lo tanto es labor del cine ayudar a borrar la percepción de la guerra heredada del régimen anterior, para promover «la creación de una memoria nueva y ejemplar» ${ }^{31}$.

Mantener esta actitud puede hacer que el divorcio de la sociedad española con su cine se acentúe. También pasó durante el franquismo ante determinadas películas, que

del periodista Carlos López Fonseca. El año siguiente la compañía de teatro y danza Arrieritos crea un espectáculo inspirado en las trece mujeres, y un año después Emilio Martínez Lázaro comienza el rodaje de la película, basándose en el libro de Fonseca. A esto se añaden otras circunstancias como la creación en 2005 de la Fundación Trece Rosas, vinculada al PSOE y presidida por el también diputado socialista José Cepeda, o la inauguración en mayo de 2006, en Getafe, de la Fuente de las Trece Rosas, entre otros hechos.

$3^{30}$ En los rótulos que aparecen al principio de la citada Libertarias por ejemplo, puede leerse: «1936. Ha comenzado la guerra civil española, la última guerra idealista, el último sueño de un pueblo volcado hacia lo imposible, hacia la utopía».

${ }^{31}$ CASANOVA, Julián, op. cit. 
con el paso del tiempo, caso de Raza, fueron consideradas excesivas aún por las mismas autoridades del régimen ${ }^{32}$. Porque lo cierto es que, se mire como se mire, los espectadores no acuden a las salas. Queda la duda de si la evidente desconexión del público español con este tipo de cine político se debe a la repulsa frente a la interpretación de nuestro pasado que encierran estas películas, al desinterés por estas cuestiones entre las viejas y las nuevas generaciones o, simple y llanamente, al rechazo hacia un cine que se considera de poca calidad, dominado por un grupo endogámico, bajo excesiva influencia oficial plasmada en una generosa política de subvenciones.

32 En 1950 sufrió una serie de mutaciones que limaban algunas asperezas ideológicas del primer franquismo para adaptarla a las realidades de la Guerra Fría: nuevo título (Espíritu de una raza), nuevo doblaje, con desaparición de referencias a Falange, y aparición de referencias mucho más explícitas al comunismo, incluyendo un rótulo de inicio que, precisamente insistía en la veracidad de lo que allí se iba a contar (habían pasado ya 11 años del final de la guerra y esta versión se iba a exhibir en Iberoamérica): «La historia que vais a presenciar no es un producto de la imaginación. Es historia pura, veraz y casi universal, que puede vivir cualquier pueblo que no se resigne a perecer en las catástrofes que el comunismo provoca». 


\section{CUADROS Y GRÁFICAS:}

\begin{tabular}{|c|c|c|}
\hline $\begin{array}{c}\text { Año } \\
\text { producción }\end{array}$ & Películas sobre Guerra Civil & $\begin{array}{c}\text { Espectadores } \\
\text { (miles) }\end{array}$ \\
\hline 2001 & SILENCIO ROTO & 429.086 \\
\hline 2002 & LA LUZ PRODIGIOSA & 71.030 \\
\hline 2002 & UNA PASIÓN SINGULAR & 8.994 \\
\hline 2003 & SOLDADOS DE SALAMINA & 433.290 \\
\hline 2003 & EL LAPIZ DEL CARPINTERO & 171.325 \\
\hline 2004 & TRIPLE AGENTE & 11.318 \\
\hline 2004 & JUEGOS DE MUJER & 51.249 \\
\hline 2006 & EL LABERINTO DEL FAUNO & 1.682 .233 \\
\hline 2007 & LAS TRECE ROSAS & 863.135 \\
\hline 2008 & LA MUJER DEL ANARQUISTA & 68.183 \\
\hline 2008 & LA BUENA NUEVA & 89.078 \\
\hline 2008 & LOS GIRASOLES CIEGOS & 738.997 \\
\hline 2010 & PAJAROS DE PAPEL & 339.025 \\
\hline 2010 & BALADA TRISTE DE TROMPETA & 349.918 \\
\hline 2010 & PAN NEGRO & 323.421 \\
\hline 2010 & CARACREMADA & 2.961 \\
\hline 2010 & ISPANSI (¡ESPANONOLES!) & 55.837 \\
\hline 2011 & ENCONTRARÁS DRAGONES & 305.502 \\
\hline
\end{tabular}

Fuente: Base de datos de películas calificadas, Ministerio de Cultura33.

33 Sección: Cine y Audiovisuales, URL:

<http://www.mcu.es/bbddpeliculas/cargarFiltro.do?layout=bbddpeliculas\&cache=init\&langua ge $=$ es $>$ [visitado entre el 10/01/2011 y el 26/07/2011]. 


\section{Cuadros y ficha técnica películas ${ }^{34}$ :}

\section{SILENCIO ROTO (2001)}

Director: Montxo Armendariz

Países participantes en la producción: ESPAÑA (100\%)

Fecha de estreno: 25 de abril de 2001

Intérpretes principales: Lucía Jiménez (Lucía), Juan Diego Botto (Manuel),

Mercedes Sampietro (Teresa), Alvaro de Luna (Don Hilario), María Botto

(Lola), María Vázquez (Sole), Rubén Ochandiano (Sebas)

Productora: ORIA FILMS,S.L.

Con la colaboración de: TELEVISIÓN ESPAÑOLA (TVE) y CANAL PLUS

Formato: $35 \mathrm{~mm}$, color, $110 \mathrm{~min}$.

\section{LA LUZ PRODIGIOSA (2002)}

Director: Miguel Hermoso

Países participantes en la producción: ESPAÑA (90.00 \%), ITALIA (10.00\%)

Fecha de estreno: 31 de enero de 2003

Intérpretes: Alfredo Landa (Joaquín), Nino Manfredi (Galápago), Kiti Manver

(Adela), José Luis Gómez (Silvio)

Productoras: AZALEA P.C., S.A., CANAL SUR TELEVISIÓN, S.A., SURF

FILMS, S.R.L. Con la participación de: VÍA DIGITAL, FORTA

Formato: $35 \mathrm{~mm}$, eastmancolor, panorámico 1:1,85, $103 \mathrm{~min}$.

\section{UNA PASIÓN SINGULAR (2002)}

Director: Antonio Gonzalo

Países participantes en la producción: ESPAÑA (100\%)

Fecha de estreno: 12 de diciembre de 2002

Intérpretes principales: Daniel Freire (Blas Infante) , Marisol Membrillo

(Angustias) , Juan Diego (Alejandro) , María Galiana (Ginesa) , Manuel Morón (Pedro Vallina)

Productoras: IMAGEN LINE, S.A., A.G. FILMS, S.A.

Con la colaboración de: CANAL SUR TELEVISIÓN

Formato: 35 mm., eastmancolor, panorámico 1:1,85, 104 min.

SOLDADOS DE SALAMINA (2003)

Director: David Trueba

Países participantes en la producción: ESPAÑA (100\%)

Género: Drama

Fecha de estreno: 21 de marzo de 2003

Intérpretes: Ariadna Gil (Lola), Ramón Fontserè (Rafael Sánchez Mazas) , Joan

Dalmau (Miralles) , María Botto (Conchi)

Productoras: LOLA FILMS, S.A., FERNANDO TRUEBA P.C., S.A.

Con la participación de: TVE, S.A., VÍA DIGITAL

Formato: 35 mm., eastmancolor, panorámico 1:1,85, $112 \mathrm{~min}$.

\section{EL LÁPIZ DEL CARPINTERO (2003)}

34 Los datos de las películas se refieren a la Base de datos de películas cualificadas del Ministerio de Cultura de España (< http://www.mcu.es >) y del The Internet Movie Database

( < http://www.imdb.com $>$ ). 
Director: Antón Reixa

Países participantes: ESPAÑA (70.00 \%), PORTUGAL (19.00 \%), REINO

UNIDO (11.00 \%)

Fecha de estreno: 25 de abril de 2003

Intérpretes: Tristán Ulloa (Daniel Da Barca), Luis Tosar (Herbal), María Adánez

(Marisa Mallo), Manuel Manquiña (Benito Mallo), Nancho Novo (Zalo)

Productoras: SOGECINE, S.A., MORENA FILMS, S.L., FILMANOVA,

TELEMADRID, TVG - TELEVISIÓN DE GALICIA, S.A., D\&D AUDIOVISUAIS

(Portugal), FISH PEOPLE LIMITED (Reino Unido)

Con la participación de: ANTENA 3 TV, CANAL+

Formato: 35 mm., color, panorámico 1:1,85, 106 min.

TRIPLE AGENTE (2004) - Triple Agente

Director: Eric Rohmer

Países participantes: ESPAÑA (10.00 \%), FRANCIA (67.00 \%), GRECIA (10.00

$\%)$, ITALIA (10.00 \%), RUSIA (3.00\%)

Fecha de estreno: 15 de octubre de 2004

Intérpretes: Serge Renko (Fiodor), Katerina Didaskalou (Arsinoé), Amanda Langlet (Janine), Emmanuel Salinger (André), Cyrielle Clair (Maguy), Grigori Manoukov (Boris), Dimitri Rafalsky (Gral. Dobrinsky)

Productoras: ALTA PRODUCCIÓN, S.L. UNIPERSONAL, TORNASOL FILMS, S.A., REZO PRODUCTIONS, SARL (Francia), COMPAGNIE ERIC ROHMER (Francia), STRADA PRODUCTIONS (Grecia), BIM PRODUZIONE (Italia), MENTOR CINEMA (Rusia)

Con la participación de: CANAL+, CINÉMACINÉMA

Formato: 35 mm., eastmancolor, panorámico 1:1,66, 105 min.

JUEGOS DE MUJER (2004) - Head in the clouds

Director: John Duigan

Países participantes: REINO UNIDO (100\%)

Fecha de estreno: 11 de octubre de 2005

Intérpretes: Charlize Theron (Gilda Bessé), Penelope Cruz (Mia), Stuart

Townsend (Guy Malyon)

Formato: $35 \mathrm{~mm} ., 122 \mathrm{~min}$.

EL LABERINTO DEL FAUNO (2006)

Dirigida por: Guillermo del Toro

Países participantes: ESPAÑA (78.00 \%), MÉXICO (22.00 \%)

Fecha de estreno: 10 de octubre de 2006

Intérpretes: Sergi López (Vidal), Maribel Verdú (Mercedes), Ivana Baquero

(Ofelia), Doug Jones (Fauno), Ariadna Gil (Carmen), Álex Angulo (Doctor)

Productoras: ESTUDIOS PICASSO FÁBRICA DE FICCIÓN, S.A., TEQUILA

GANG (México), ESPERANTO FILMOJ S.A. DE C.V. (México)

Con la participación de: TELECINCO y SENTENTIA ENTERTAINMENT

Formato: 35 mm., Color Kodak Vision2 200T 5217, 500T 5218, Vision2 5oD

5246, Intermediate digital, panorámico 1:1,85, $121 \mathrm{~min}$.

\section{LAS TRECE ROSAS (2007)}


Director: Emilio Martínez-Lázaro

Países participantes: ESPAÑA (80.00 \%), ITALIA (20.00 \%)

Fecha de estreno: 14 de septiembre de 2007

Intérpretes: Pilar López de Ayala (Blanca), Verónica Sánchez (Julia), Marta Etura (Virtudes), Nadia de Santiago (Carmen), Gabriella Pession (Adelina), Félix Gómez (Perico), Fran Perea (Teo), Enrico Lo Verso (Cánepa), Asier Etxeandía (Enrique), Alberto Ferreiro (Valentín), Adriano Giannini (Fontenla), Goya Toledo (Carmen Castro), Bárbara Lennie (Dionisia), Luisa Martín (Dolores), Teresa Hurtado de Ory (Victoria), Natalia Menéndez (M ${ }^{\mathrm{a}}$ Teresa), Secun de la Rosa (Satur), Juan Gea (Gabaldón)

Productoras: ENRIQUE CEREZO P.C., S.A., PEDRO COSTA P.C., S.A., FILMEXPORT GROUP SRL (Italia)

Con la participación de: TVE, S.A., CANAL+ (España)

Formato: 35 mm., color, Scope 1/2'35, 130 min.

\section{LA MUJER DEL ANARQUISTA (2008)}

Director: Marie Noëlle, Peter Sehr

Países participantes: ALEMANIA (46.00 \%), ESPAÑA (31.00 \%), FRANCIA (23.00\%)

Fecha de estreno: 30 de diciembre de 2008

Intérpretes: Juan Diego Botto (Justo), María Valverde (Manuela), Ivana

Baquero (Paloma), Nina Hoss (Lenin)

Productoras: ZEPPELINS INTEGRALS PRODUCCIONS, S.L., P'ARTISAN

FILMPRODUKTION GMBH (Alemania), CINÉ BOISSIÈRE (Francia)

Con la participación de: TVE, S.A., TELEVISIÓ DE CATALUNYA, S.A., KV

ENTERTAINMENT, BAYERISCHER RUNDFUNK, MESFILMS, ARTE, RHÔNES-ALPES CINÉMA, RIOT ENTERTAINMENT, INSTINCTIVE FILM Formato: 35 mm., color Fujifilm, panorámico 1:1,85, 125 min.

\section{LA BUENA NUEVA (2008)}

Director: Helena Taberna

Países participantes: ESPAÑA (100\%)

Fecha de estreno: 14 de noviembre de 2008

Intérpretes: Unax Ugalde (Miguel), Bárbara Goenaga (Margari), Gorka

Aginagalde (Hugo), Guillermo Toledo (Antonino), Joseba Apaolaza (obispo), Mikel Tello (capitán de falange)

Productora: LAMIA PRODUCCIONES AUDIOVISUALES, S.L.

Con la participación de: TVE, S.A., ETB, S.A.

Formato: 35 mm., color, panorámico 1:1,85, 104 min.

\section{LOS GIRASOLES CIEGOS (2008)}

Director: José Luis Cuerda

Países participantes: ESPAÑA (100\%)

Fecha de estreno: 28 de agosto de 2008

Intérpretes: Maribel Verdú (Elena), Javier Cámara (Ricardo), Raúl Arévalo (Salvador), Roger Princep (Lorenzo), Irene Escolar (Elenita), Martìn Rivas (Lalo)

Productoras: SOCIEDAD GENERAL DE CINE, S.A. (SOGECINE), PRODUCCIONES A MODIÑO, S.L., ESTUDIOS ORGANIZATIVOS Y 
PROYECTOS CINEMATOGRÁFICOS, S.L., PRODUCCIONES LABAROUTA, S.L.

Con la participación de: TVE, S.A., CANAL+ (España), TVG

Formato: $35 \mathrm{~mm} ., 101 \mathrm{~min}$.

PAJAROS DE PAPEL (2010)

Director: Emilio Aragón

Países participantes: ESPAÑA

Fecha de estreno: 12 de marzo de 2010

Intérpretes: Imanol Arias (Jorge del Pino), Lluís Homar (Enrique Corgo), Roger Princep (Miguel)

Productoras: VERSÁTIL CINEMA, S.L., GLOBO MEDIA, S.A., ANTENA 3

FILMS, S.L.

Con la participación de: CANAL+, SOCIEDAD DON QUIJOTE DE CASTILLA

LA MANCHA

Duración: 125 min.

BALADA TRISTE DE TROMPETA (2010)

Director: Álex de la Iglesia

Países participantes: ESPAÑA (90.00 \%), FRANCIA (10.00 \%)

Fecha de estreno: 17 de diciembre de 2010

Intérpretes: Carlos Areces (Javier), Antonio de la Torre (Sergio), Carolina Bang (Natalia)

Productoras: TORNASOL FILMS, S.A., CASTAFIORE FILMS, S.L., LA

FABRIQUE 2 (Francia)

Con la participación de: TVE - TELEVISIÓN ESPAÑOL, CANAL+ (España), CANAL+ (Francia/France), CIUDAD DE LA LUZ, en asociación con: MIKADO FILMS, UFUND Y UFUND, BACKUP FILMS

Formato: HD a $35 \mathrm{~mm}$. , scope 1:2,35, $101 \mathrm{~min}$.

PAN NEGRO (2010) - Pa Negre

Director: Agustí Villaronga

Países participantes: ESPAÑA (100\%)

Fecha de estreno : 15 de octubre de 2010

Intérpretes: Francesc Colomer (Andreu), Marina Comas (Núria), Nora Navas

(Florència), Roger Casamajor (Farriol), Sergi López (alcalde)

Productoras: MASSA D'OR PRODUCCIONS, S.L., TELEVISIÓ DE

CATALUNYA, S.A.,

Con la participación de: TVE

Formato: $35 \mathrm{~mm}$., panorámico 1:1,85, $108 \mathrm{~min}$. 
CARACREMADA (2010)

Director: Lluís Galter

Países participantes: ESPAÑA (100\%)

Fecha de estreno: 18 de noviembre de 2010

Intérpretes: Lluís Soler (Ramón Vila "Caracremada"), Aina Calpe (Danaide) Productoras: MALLERICH FILMS PACO POCH, S.L., CROMOSOMA, S.A. Con la participación de: TELEVISIÓ DE CATALUNYA, S.A., ASSOCIACIÓ CULTURAL PASSOS LARGS

Formato: DIGITAL, 1:1,77, $98 \mathrm{~min}$.

ISPANSI ( (ESPAÑOLES!) (2010)

Director: Carlos Iglesias

Países participantes: ESPAÑA (80.00 \%), SUIZA (20.00 \%)

Fecha de estreno: 26 de noviembre de 2010

Intérpretes: Esther Regina (Paula), Carlos Iglesias (Álvaro)

Productoras: UN FRANCO 14 PESETAS, S.L., MAESTRANZA FILMS, S.L.,

SAGA PRODUCTIONS S.A.R.L.

Con la participación de: TVE, CANAL SUR TV, RADIO TÉLÉVISION SUISSE

(Suiza/Switzerland)

ENCONTRARÁS DRAGONES (2011) - There be Dragons

Director: Roland Joffé

Países participantes: ESPAÑA (60.00 \%), ESTADOS UNIDOS (40.00 \%)

Fecha de estreno: 15 de marzo de 2011

Intérpretes: Charlie Cox (Josemaría Escrivá), Wes Bentley (Manolo), Dougray Scott (Robert), Unax Ugalde (Pedro), Olga Kurylenko (Ildiko)

Productoras: ANTENA 3 FILMS S.L., MOUNT SANTA FE ESPAÑA, A.I.E., NFOCUS PRODUCTIONS (Estados Unidos /USA)

Duración: 117 min. 


\section{Gráficos 35 :}

\begin{tabular}{|c|c|c|c|c|}
\hline Año & Películas $^{36}$ & $\begin{array}{l}\text { datos espect. } \\
\text { p. Guerra } \\
\text { Civi }\end{array}$ & $\begin{array}{l}\text { datos espect. p. } \\
\text { p. producción } \\
\text { nacional }\end{array}$ & $\begin{array}{c}\text { datos p. más vistas en } \\
\text { España (también } \\
\text { extranjeras) }\end{array}$ \\
\hline 2001 & $\begin{array}{l}\text { SILENCIO ROTO } \\
\text { Los Otros } \\
\text { Señor de los anillos: la } \\
\text { comunidad del anillo }\end{array}$ & 429.086 & 6.410 .461 & 7.026 .478 \\
\hline 2002 & $\begin{array}{c}\text { LA LUZ PRODIGIOSA } \\
\text { UNA PASIÓN SINGULAR } \\
\text { El otro lado de la cama } \\
\text { Spiderman }\end{array}$ & $\begin{array}{l}71.030 \\
8.994\end{array}$ & 2.726 .871 & 5.232 .518 \\
\hline 2003 & $\begin{array}{c}\text { SOLDADOS DE SALAMINA } \\
\text { EL LAPIZ DEL } \\
\text { CARPINTERO } \\
\text { La Gran aventura de Mortadelo } \\
\text { y Filemón } \\
\text { Piratas del Caribe. La } \\
\text { maldición de la perla negra } \\
\end{array}$ & $\begin{array}{l}433.290 \\
171.325\end{array}$ & 4.979 .991 & 4.847 .651 \\
\hline 2004 & $\begin{array}{c}\text { TRIPLE AGENTE } \\
\text { JUEGOS DE MUJER } \\
\text { Mar Adentro } \\
\text { Shrek } 2 \\
\end{array}$ & $\begin{array}{l}11.318 \\
51.249\end{array}$ & 3.998 .550 & 6.195 .877 \\
\hline 2006 & $\begin{array}{c}\text { EL LABERINTO DEL } \\
\text { FAUNO } \\
\text { Alatriste } \\
\text { Piratas del Caribe. El cofre del } \\
\text { hombre muerto }\end{array}$ & 1.682 .233 & 3.130 .710 & 5.411 .994 \\
\hline 2007 & $\begin{array}{c}\text { LAS TRECE ROSAS } \\
\text { El Orfanato } \\
\text { Piratas del Caribe. En el fin del } \\
\text { Mundo }\end{array}$ & 863.135 & 4.274 .355 & 4.095 .364 \\
\hline 2008 & $\begin{array}{c}\text { LA MUJER DEL } \\
\text { ANARQUISTA } \\
\text { LA BUENA NUEVA } \\
\text { LOS GIRASOLES CIEGOS } \\
\text { Los crimenes de Oxford } \\
\text { Indiana Jones y el reino de la } \\
\text { calavera de cristal }\end{array}$ & $\begin{array}{c}68.183 \\
89.078 \\
738.997\end{array}$ & 1.421 .063 & 3.555 .840 \\
\hline 2010 & $\begin{array}{c}\text { PAJAROS DE PAPEL } \\
\text { BALADA TRISTE DE } \\
\text { TROMPETA } \\
\text { PAN NEGRO }\end{array}$ & $\begin{array}{l}339.025 \\
349.918 \\
323.421\end{array}$ & & \\
\hline
\end{tabular}

35 Fuente: < http://www.mcu.es >; los datos se refieren únicamente a la proyección de las películas en cines españoles; datos espect. p. > "datos espectadores películas".

${ }^{36} \mathrm{El}$ listado toma en consideración todas las películas utilizadas para los gráficos. Los títulos en mayúscula representan las películas analizadas sobre la guerra civil. 


\begin{tabular}{|c|c|c|c|} 
CARACREMADA & 2.961 & \\
ISPANSI (¡ESPAÑOLES!) & 55.837 & \\
Tres metros bajo el cielo & & \\
& Avatar & & \\
& & & \\
& Encontrarás Dragones & 305.502 & \\
\end{tabular}




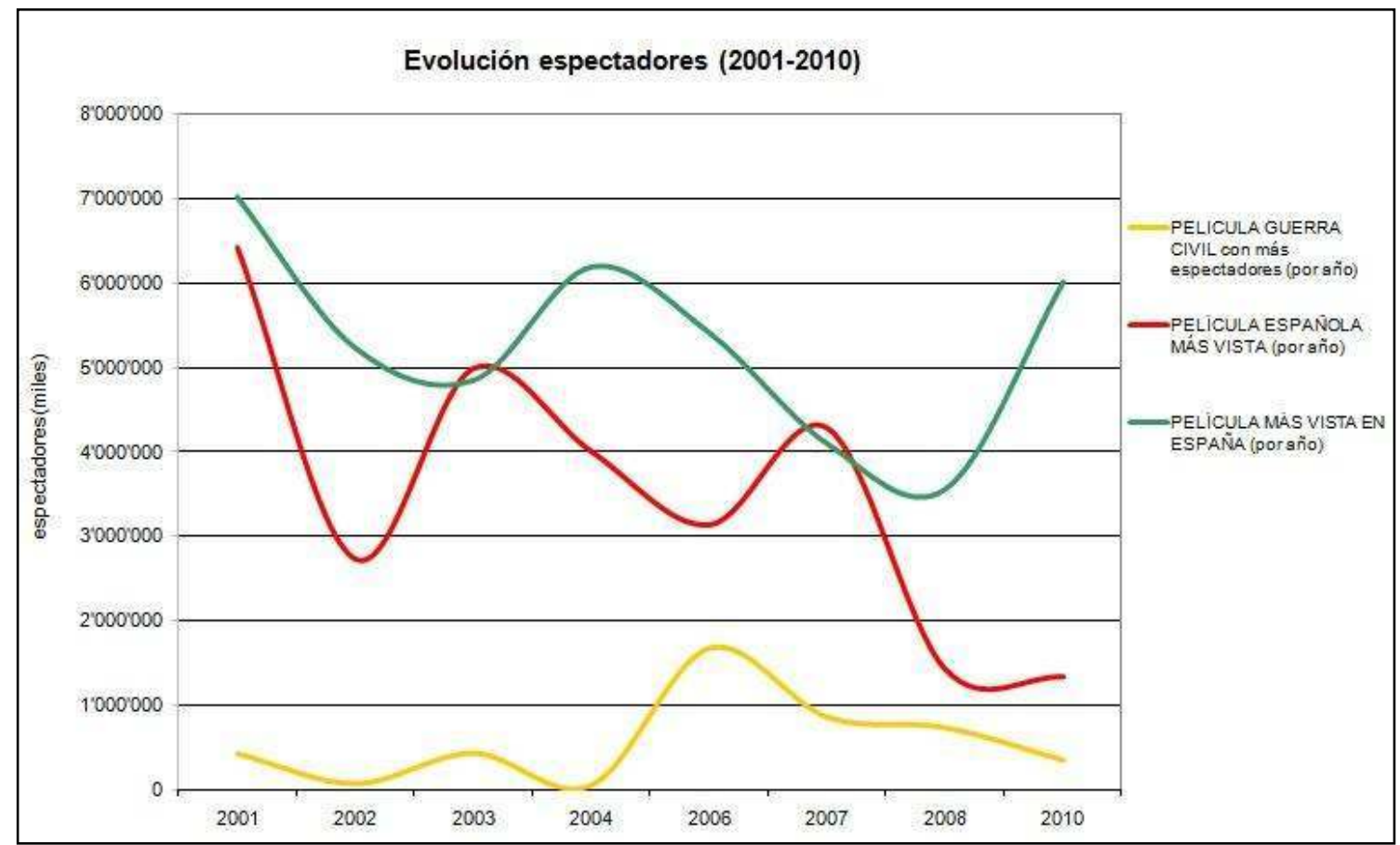

Comparación (por año) de espectadores: películas Guerra Civil, películas españolas más vista y película más vista en España.

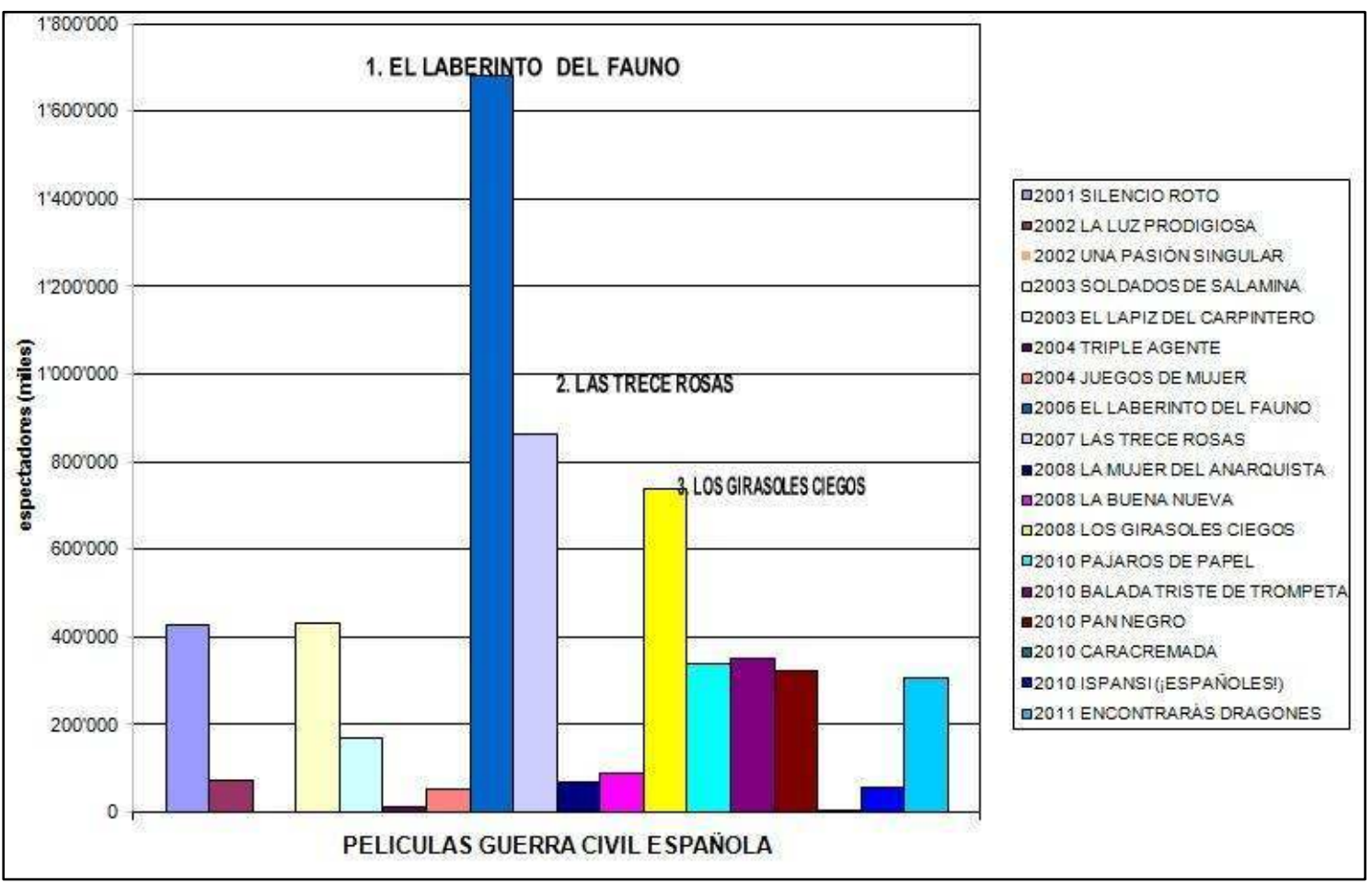

Espectadores (miles) de las películas sobre la Guerra Civil analizadas en este artículo. 


\section{Autores}

*José-Vidal Pelaz López es Profesor Titular de Historia Contemporánea en la Facultad de Filosofía y Letras de la Universidad de Valladolid. Entre sus líneas de investigación preferentes destacan la Historia de la comunicación social y la Historia política reciente. En relación a la primera podemos citar sus libros Caciques, apóstoles y periodistas. Medios de comunicación, poder y sociedad en Palencia (1898-1939) (2000) y Ver cine. Los públicos cinematográficos en el siglo $X X$ (2002). Respecto a la segunda El Estado de las Autonomías. Nacionalismos y regionalismos en la Historia Contemporánea de España (2002), Winston Churchill. Auge y declive del Imperio británico (2003) y Castilla y León en democracia. Partidos, elecciones y personal político (1977-2007) (2007). Ha publicado también numerosos capítulos de libros y artículos en publicaciones especializadas.

URL: < http://studistorici.com/progett/autori/\#PelazLopez >

**Matteo Tomasoni, se ha licenciado en Historia Contemporánea en la Università di Bologna (2008) y desde 2009 es doctorando en la Universidad de Valladolid. Se ocupa de temas relacionados con la historia contemporánea de España, dedicándose especialmente al análisis de la Segunda República y de los movimientos pertenecientes a la extrema derecha española de los años Treinta: La conquista del Estado, JCAH, JONS y Falange Española. Colabora además en otros proyectos académicos y es miembro de la redacción de Diacronie.

URL: http://www.studistorici.com/2008/09/14/matteo-tomasoni/

\section{Per citare questo articolo:}

PELAZ LÓPEZ, José-Vidal, TOMASONI, Matteo, «Cine y Guerra civil El conflicto que no termina», Diacronie. Studi di Storia Contemporanea: Spagna Anno Zero: la guerra come soluzione, 29/07/2011,

URL:<:<http://www.studistorici.com/2011/07/29/tomasoni2_numero_7>>

Diacronie Studi di Storia Contemporanea $\beta$ www.diacronie.it

Risorsa digitale indipendente a carattere storiografico. Uscita trimestrale. redazione.diacronie@hotmail.it

Comitato di redazione: Marco Abram - Giampaolo Amodei - Jacopo Bassi - Luca Bufarale - Alessandro Cattunar - Alice De Rensis Barbara Galimberti - Deborah Paci - Fausto Pietrancosta - Martina Sanna - Matteo Tomasoni - Luca Zuccolo

Diritti: gli articoli di Diacronie. Studi di Storia Contemporanea sono pubblicati sotto licenza Creative Commons 2.5

Possono essere riprodotti a patto di non modificarne i contenuti e di non usarli per fini commerciali. La citazione di

estratti è comunque sempre autorizzata, nei limiti previsti dalla legge. 